\title{
CHALLENGES AND POTENTIAL TO ADOPT BIOGAS TECHNOLOGY: A CASE STUDY OF FAISALABAD, PAKISTAN
}

\author{
aHafiz U. Shahzad*, aMuhammad F. Mustafa, bZohaib U. Afridi \\ ${ }^{a}$ Department of Environmental Design, Health and Nutritional Sciences, Allama Iqbal Open University Islamabad, \\ Pakistan. \\ ${ }^{b}$ Department of Energy Management and Sustainability, University of Engineering and Technology Peshawar, Pakistan.
}

\section{ART ICLE INFO}

\section{Article history}

Received: July 29, 2020

Revised: October 10, 2020

Accepted: December 23, 2020

\section{Keywords \\ Biogas \\ Resources \\ Renewable energy \\ Trading \\ Bio-digester}

\section{A B S T R A C T}

In the past few years, pertaining to energy shortage, Government of Pakistan promoted the biogas plants in specific rural areas. This study is an attempt to explore the success and failure adopted biogas plants by the farmers in rural areas of Faisalabad, Pakistan. In this study, the researcher selected tehsil Faisalabad of district Faisalabad based on the availability of biogas plants installed by the Government, NGO/INGOs and private contractors in the past few years. Snowball sampling method was used to identify the sample size. Total 51 biogas adopters participated in the study as respondents. Primary data were collected through face to face interviews on a structured questionnaire. Results shows that $33.3 \%$ of respondents were fully satisfied with their biogas plants. Close to one fourth $(23.5 \%)$ of respondents were partially satisfied while $43.1 \%$ of respondents were not satisfied with their biogas plants. More than half $(56.9 \%)$ of biogas plants were in working condition and $43.1 \%$ of biogas users abandoned for many reasons. The major reasons for the inspiration behind construction and installation of biogas plants were subsidy, cases of existing biogas plant owners, social advantages/reputation, motivation from construction/installation agency and conservation of time and energy. Whereas, for the reasons such as frequently come across technical problems, unavailability of technicians, difficulty in operation of biogas plant, insufficient gas for food preparation /lighting, escape of gas through joints/connections and extra workload were the reasons compelling farmers to abandoning the biogas plants. It was found that operation and maintenance of biogas plants is one of the major issues due to untrained, partially trained owners, unavailability of technicians and skilled operators.

Corresponding Author: Hafiz Usama Shahzad

Email: usama.shahzad@hotmail.com

(C) The Author(s) 2020.

\section{INTRODUCTION}

Energy for sustainable development is of critical importance. Developing countries around the world are already facing the severe economic burden in the form of oil and gas import. Pakistan is one of those nations where a hefty amount of national exchequer is energy consumed on import of oil and gas in order to meet the energy shortage. The energy import bill of Pakistan was estimated as 9.1 Billion dollars for the fiscal year 20182019 (GoP, 2018). It is a well- known fact that energy and economic development are highly interdependent (Oyeleke and Akinlo, 2020). 
Many low-middle income countries around the world have invested in renewable energy technologies such as biomass, hydro, solar thermal etc., to produce indigenous, affordable and reliable energy (Morgan et al., 2018), (Pham et al., 2017), (Prochnow et al., 2009). Biogas generation from organic waste through anaerobic digestion has been reported as a sustainable energy source (Afridi et al., 2019). Many studies have reported that biogas not only provides energy for the rural areas in particular but also bridges the gap in improving health, reducing poverty and creating local job market for economic growth (Aberilla et al., 2020), (Bates et al., 2019), (Hettiarachchi et al., 2018). Biogas production has many environmental benefits as well like waste treatment, sustainable energy \& power production and use of bio-slurry as organic fertilizer to develop a vigour in crops. Due to sluggish growth and energy shortage in rural areas of low-middle income countries, lack of biogas production leads to deforestation. Thus, women bear the burden of wood cutting and burning for heating and cooking purposes (Rosenthal et al., 2018). Agriculture is augmented as lifeline for Pakistani economy. Major chunk of population in Pakistan earns their livelihood from the agriculture. Thus, use of biogas slurry in agriculture, if promoted well can curtail the cost of fertilizers and improve the soil health and production of crops eventually (Afridi and Qammar, 2020). Collection of bio-slurry through process of biogas generation was augmented effective for the soil fertility by the biogas users (Ashraf et al., 2019).

Livestock is integral part of agriculture and Pakistan is one of the prominent nations in the world where livestock contributes significantly to the economy and development of livelihoods. It is estimated that 650 Million $\mathrm{Kg} /$ day of animal dung is produced in Pakistan and even if $50 \%$ is collected and processed, the country can provide 16.25 million $\mathrm{m} 3 /$ day of biogas to consumers. This amount of biogas can help in rural support and energy poverty eradication (Ashraf et al., 2019). Agriculture is an important sector of Pakistan; livestock is sub-sector of Pakistan agriculture. Agriculture contributes $19.3 \%$ to the Gross Domestic Product (GDP) of Pakistan followed by the $11.7 \%$ share contributed by livestock sector (GoP, 2019). Current population of livestock in Pakistan is estimated as 207.4 million. Greater than 8 million farm families are directly engaged in livestock production and collecting 35-40\% of their total income from livestock (GoP, 2019).
(Rehman et al., 2017) had associated milk, fat, eggs. bones and mutton with the significant growth of economy. This implies, with the development of livestock products the farmers earn adequate income (Alvi et al., 2015).

The role of livestock is viewed important generating energy such as biogas, which could be an alternative cost-effective energy source specially when the country like Pakistan is meeting $28.12 \%$ of energy through oil and gas import (Younos et al., 2012). Many studies such as (Ashraf et al., 2019), (Amer and Daim, 2011), and (Jamil and Ahmad, 2010) have suggested the bright future of biogas technology in Pakistan and its prospects of helping meeting the energy deficit in country. The huge population of animals across the Pakistan further accentuate the potential of biogas generation through the animals' dung. (Shah and Sahito, 2017) calculated 129 ton/day collection of animal dung in Pakistan which could help in producing adequate quantity of biogas. According to (Akinbami et al., 2001), from each $\mathrm{kg}$ of animal dung average $0.03 \mathrm{~m} 3$ biogas can be produced. Whereas, taking the statistics into account, average 12$804 \mathrm{~m} 3$ /day biogas can be produced in villages of Pakistan from the animal dung (Shah and Sahito, 2017).

In order to benefit from the biogas technology, the Government of Pakistan initiated a biogas project in 1974 and installed 4137 biogas plants by 1987 in the rural areas. The designed capacities of plants were 3000 $\mathrm{ft}^{3}$ to $5000 \mathrm{ft}^{3}$ of biogas per day for lighting and cooking purpose (Chaudhry et al., 2009). In order to provide biogas plant as a replacement for conventional fuels (wood, animal dung cake, liquefied petroleum gas and crops leftover), Pakistan Domestic Biogas Program started a project in 2009 (Akram et al., 2017).

The objective of this program was to construct 12000 biogas Plants. Unfortunately, the desired target was not achieved and estimated 3000 biogas plants were installed. For social and technological adaptation, the program offered subsidy as an incentive to encourage people of the rural area, but the acceptance of biogas technology has low encouraged rate (Mushtaq et al., 2016). On the other hand, regional countries such as Nepal, China, India, and Bangladesh have a higher number of biogas plants which are running very successfully (Nevzorova and Kutcherov, 2019). Thus, it is important to find out the important factors, which affect the acceptance rate of biogas technology. Although biogas technology is technically possible, 
environmentally sustainable and economically attractive, still it is not socially acceptable in Pakistan. There is a significant gap of knowledge in the existing literature about the influence of critical factors (institutional, market and family 's choice of fuel source etc.) on the adoption rate of rural Pakistani communities to build, accept and practice successful biogas plant applications. Few of the studies such as (Iqbal et al., 2013), (Abbas et al., 2017), (Amir et al., 2020) and (Ashraf et al., 2019) are found in literature focusing in biogas with special reference to Pakistan. However, these studies were mainly focused on adoption of biogas technology. None of the study examined that why farmers were abandoning the biogas technology and what reasons are compelling to do so. Therefore, this study was conducted to examine the different factors hampering the adoption of biogas technology among farmers and what reasons are compelling them to abandon the biogas technology use. Finding of this study will help the authorities (Govt. and NGO/INGO) to reduce the weaknesses of the process by identifying, focusing and taking appropriate actions to spread awareness in future biogas development programmes.

In this study, the critical social and technical reasons for the adoption of the installed biogas plants in rural areas of Faisalabad, Pakistan were investigated. Faisalabad tehsil was chosen for the study because according to a report KN-RSPN Pakistan Domestic Biogas Programme (PDBP) published on a website of Rural Support Programmes Network (RSPN) shown that most of the biogas plants (10 plants annually) were installed there during the project phase ${ }^{1}$. This study will provide original data of installation, operation, and usage adaptation pattern of farmers for acceptance of the biogas energy technology. This study is of importance for the authorities (Government, NGO, and INGO) to reduce the weaknesses of the process by identifying, focusing and taking appropriate actions to spread awareness in future biogas development programs.

\section{Theoretical Framework}

Energy choice theory is the theoretical basis of this study. The energy choice theory can be applied in this

\footnotetext{
${ }^{1}$ EKN-RSPN Pakistan Domestic Biogas Programme (PDBP). http://www.rspn.org/index.php/completedprojects/ekn-rspn-pakistan-domestic-biogasprogramme-pdbp/
}

study as the area under study has the potential to choose between biogas from agriculture waste or connect with a national grid of Sui gas or other alternatives, depending upon the availability of gas connections. The choice to choose a specific fuel for any household is usually based on the 'energy ladder' model. It is a linear process to switch between different types of fuels. At the bottom, we have traditional (firewood, dung cakes, shrubs) and the top consists of modern fuels (Methane gas and electric stoves) based on the average household income. This model emphasizes income in explaining energy choice (Baland et al., 2010).

(Heltberg, 2005) reported that countries around the world attempt to explore renewable energy sources as they primarily fail to meet the clean energy demands of their population through conventional sources. Wealth and economic status were the key factors for this theory. However, other critical factors such as environmental concerns, use of reliable technology, demographic and social aspect for technology adaptation are also critical (Masera et al., 2000). Based on this theoretical background, the study was conducted to identify the adopting factors for biogas plants in Pakistan. It was assumed that social, technical, and environmental factors could not be ruled out for the success or failure of the biogas plants by a community or end-user. The survey conducted in this study considers all aforementioned factors along with the investigation of factors to select sustainable and indigenous biogas production, purchasing firewood, LPG etc., or rely upon government-provided gas connection. The theoretical framework can provide a better picture of consumer perception about the choice of energy source for livelihood.

\section{MATERIALS AND METHODS}

In this study, Faisalabad tehsil was selected based on agriculture, employment and availability of biogas plants as shown in Figure 1. The target study population was 150 number of biogas plant users located in 28 villages in tehsil Faisalabad of districted Faisalabad Pakistan. Snowball (non-probability) sampling technique was used to collect primary data. This process started with a few numbers of respondents who increased gradually. The sample size was defined until the saturation point (A saturation point reached when the researcher starts getting the same data from the respondents) arrived i.e. 51 number of biogas respondents. This sampling method 
was used because of fewer numbers of participants. This process helped the researcher to approach the undiscovered respondents. The research questionnaire was developed and pre-tested by the author after considering existing literature, initial site visits, interviewing biogas users and discussion with field experts. The primary data was collected by site visits,

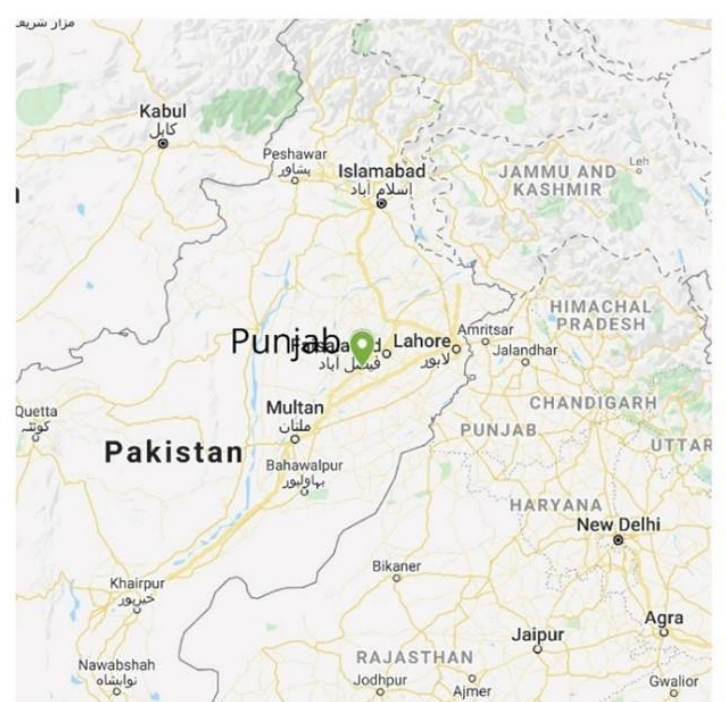

Figure 1. Biogas Plants visited in 28 Villages of Tehsil Faisalabad, Pakistan.

\section{RESULTS AND DISCUSSION}

\section{Adaptive Factors}

The descriptive data of variable adaptive factors variables are listed in Table 1 . The major reason for the inspiration behind the construction and installation of biogas plants were subsidy and saving of time and energy. These are the major reasons that made a lot of people to accept biogas plants among rural areas of Faisalabad. Subsidy and motivation from an existing plant owner were accounting for $41 \%$. The role of finance, tax and subsidy aspect was the Key influencing face to face interviews, observations, and questionnaire. Secondary data was collected from existing published reports and other research studies. Data collected from 51 number of respondents was coded in Microsoft Excel and then the data was fed to SPSS version 23.0. for analysis.

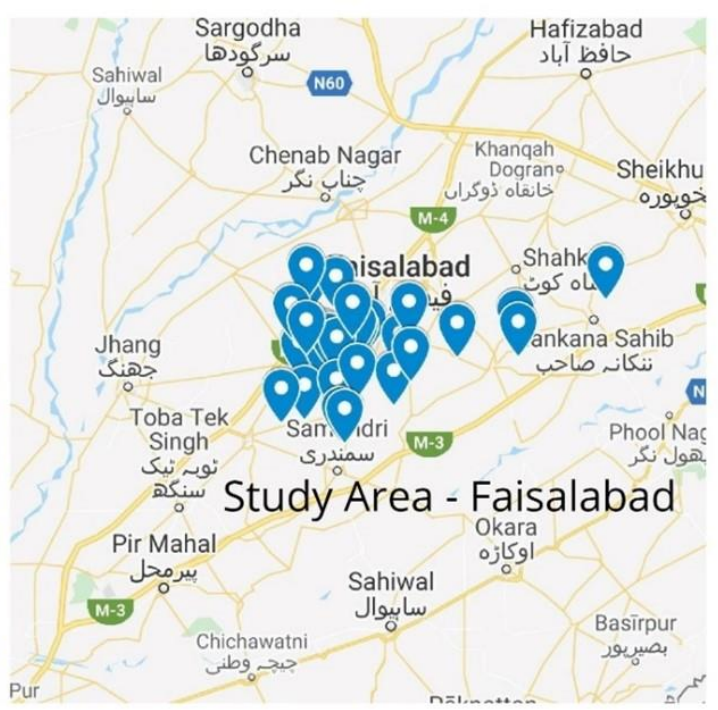

factor for the adoption of cleaner fuels (Puzzolo et al., 2016). Other motivational factors included time-saving and social reputation as $32 \%$ each, respectively. It is worth mentioning that in low-middle income countries, technology progress is highly linked with social acceptance. (Pilloni et al., 2020) highlighted the fact that social niche instigates an individual's behavior and links it to existing social practices. The lowest case percentage was $13.7 \%$ refereeing to health advantages. This can be attributed to the level of awareness of the adopter.

Table 1. Reasons of Inspiration about the Biogas Plant.

\begin{tabular}{lccc}
\hline Reasons & Frequency & Percent of response (\%) & Percent of cases (\%) \\
\hline Subsidy & 21 & 13.7 & 41.2 \\
Unavailability of other fuels at that time & 10 & 6.5 & 19.6 \\
Environmental advantages & 9 & 5.9 & 17.6 \\
Economic advantages & 12 & 7.8 & 23.5 \\
Save time & 15 & 9.8 & 29.4 \\
Save energy & 15 & 9.8 & 29.4 \\
Social advantages / reputation & 16 & 10.5 & 31.4 \\
Health advantages & 7 & 4.6 & 13.7 \\
Motivation form existing plants & 21 & 13.7 & 41.2 \\
\hline
\end{tabular}




\begin{tabular}{lccc}
\hline Motivation from construction body & 16 & 10.5 & 31.4 \\
\hline $\begin{array}{l}\text { Table 2. Views of fully satisfied users of biogas plant. } \\
\text { Description }\end{array}$ & Frequency & Percent of response (\%) & Percent of cases (\%) \\
\hline $\begin{array}{l}\text { Sufficient gas for food preparation/lighting } \\
\text { Easy operation of biogas plant }\end{array}$ & 7 & 7.4 & 13.7 \\
$\begin{array}{l}\text { Cooking become easy } \\
\text { Availability of }\end{array}$ & 6 & 6.3 & 11.8 \\
$\begin{array}{l}\text { Technicians } \\
\text { Health }\end{array}$ & 3 & 3.2 & 5.9 \\
$\begin{array}{l}\text { Advantages } \\
\text { Economic }\end{array}$ & 10 & 10.5 & 19.6 \\
$\begin{array}{l}\text { Advantages } \\
\text { Social repute }\end{array}$ & 3 & 3.2 & 5.9 \\
$\begin{array}{l}\text { Environmental } \\
\text { Advantages }\end{array}$ & & & 11.8 \\
$\begin{array}{l}\text { Reduction in } \\
\text { Workload }\end{array}$ & 6 & 6.3 & 9.8 \\
$\begin{array}{l}\text { Food prepared in biogas is tastier } \\
\text { Cleaner food } \\
\text { preparation } \\
\text { utensils }\end{array}$ & 5 & 5.3 & 7.8 \\
$\begin{array}{l}\text { Others } \\
\text { None }\end{array}$ & 4 & 4.2 & 7.8 \\
\hline
\end{tabular}

Table 2, shows that the major reasons due to which the respondents of rural areas of Faisalabad are fully satisfied with their biogas plants. The identified reasons are the availability of technicians, enough gas for food preparation, lighting, economic advantages, easy operation of biogas plant and social repute. In general, the availability of technical service is driving satisfactory force for social development projects such as in the case of Nepal, Bangladesh, and India (Shrestha and Dhakal, 2019), (Breitenmoser et al., 2019), (Matter et al., 2015). Table 3. Information about Operation of Existing Biogas Plants.

\begin{tabular}{|c|c|c|c|c|}
\hline Variable & Description & Frequency & Percentage (\%) & Mean \pm St. Dev. \\
\hline \multirow{3}{*}{$\begin{array}{l}\text { Biogas plant is currently not working / } \\
\text { failed; will you accept it in future with } \\
\text { some modifications }\end{array}$} & Yes & 17 & 33.3 & \multirow{3}{*}{$2.24 \pm 0.929$} \\
\hline & No & 5 & 9.8 & \\
\hline & $\begin{array}{l}\text { Plants presently } \\
\text { working }\end{array}$ & 29 & 56.9 & \\
\hline
\end{tabular}

About $56 \%$ of the respondents did not answer. Farmers were further inquired about their willingness to either revise their failed biogas plants or not (Table 3). Of the total respondents, 33\% agreed to utilise the technology followed by $9.8 \%$ of respondents who didn't agreed with the revival of biogas plants. More than half (56.9\%) of respondents reported their biogas plants in in functional condition. The few glimpses of working biogas plants is illustrated in Figure 2. 


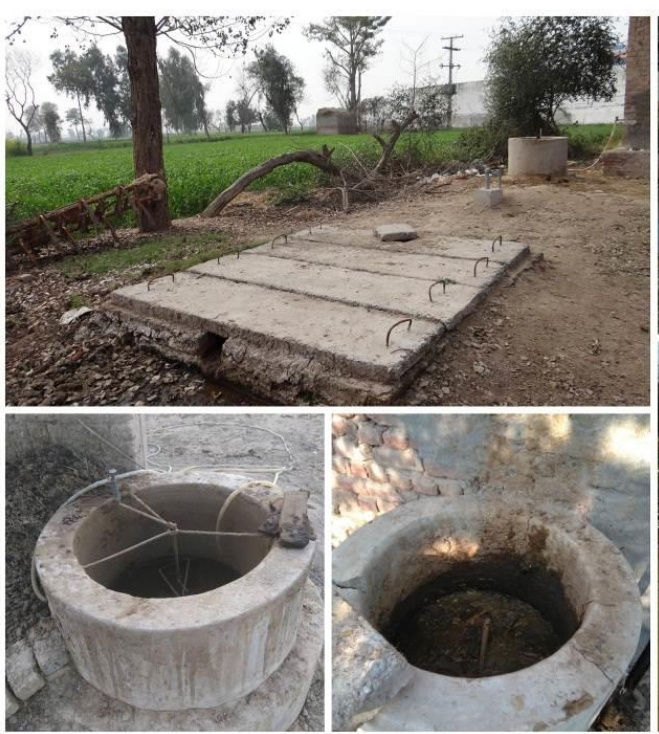

Figure 2. Visuals of active biogas plants in study areas.

\section{Financial Benefits}

Table 4 shows that, $57 \%$ of respondents agreed that they saved fuel expenditure, while $43 \%$ did not agree. Saving in fuel cost has been reported in recent studies in lowmiddle income countries (Clemens et al., 2018), (Wang and Calderon, 2012). Furthermore, $35 \%$ of respondents reported a positive change in the financial status of $\mathrm{HH}$

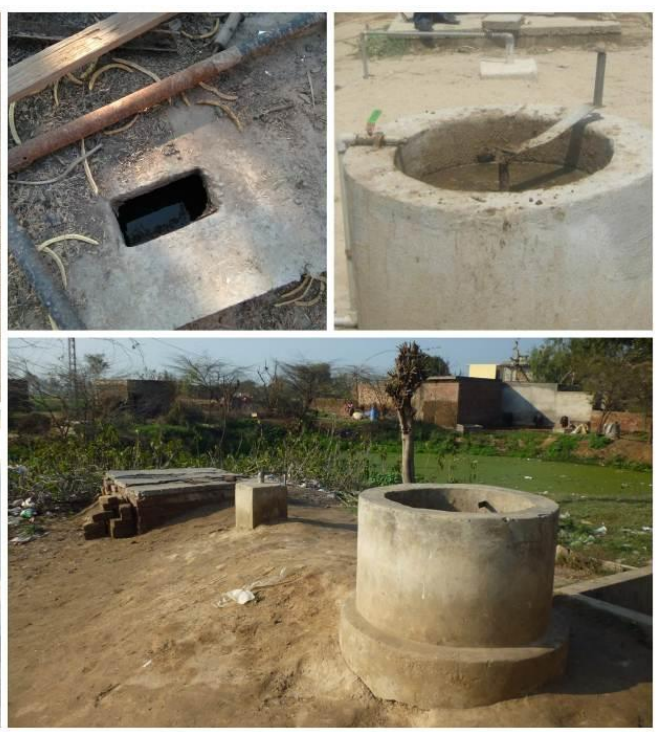

after the installation of a biogas plant whereas $51 \%$ reported no change in financial status. This change is attributed to the number of members and expenditures of family members. Nuclear families tend to save more whereas joint families in rural areas of Pakistan contribute equally to support each other. This can be the reason for $51 \%$ of the family could not save the money.

Table 4. Saving of conventional fuel resources of household.

\begin{tabular}{|c|c|c|c|c|}
\hline Variable & Description & Frequency & Percentage & Mean \pm St. dev \\
\hline \multirow{2}{*}{$\begin{array}{l}\text { Do you think you have saved fuel } \\
\text { after construction / installation of } \\
\text { biogas plant }\end{array}$} & Yes & 29 & 56.9 & \multirow[b]{2}{*}{$1.43 \pm 0.500$} \\
\hline & No & 22 & 43.1 & \\
\hline \multirow{4}{*}{$\begin{array}{l}\text { Either expenditure has been gone } \\
\text { down after the installation of biogas } \\
\text { plant construction }\end{array}$} & No & 18 & 35.3 & \multirow{4}{*}{$2.14 \pm 1.020$} \\
\hline & To some extent & 13 & 25.5 & \\
\hline & $\begin{array}{l}\text { Significantly } \\
\text { gone down }\end{array}$ & 15 & 29.4 & \\
\hline & Gone up & 5 & 9.8 & \\
\hline \multirow{3}{*}{$\begin{array}{l}\text { Change in financial status after } \\
\text { installing biogas plant }\end{array}$} & Improving & 18 & 35.3 & \multirow{3}{*}{ - } \\
\hline & Decreasing & 7 & 13.7 & \\
\hline & No change & 26 & 51.0 & \\
\hline
\end{tabular}

The expenditures of fully pleased users are significantly reduced after the installation of a biogas plant. This is one of the major adaptive reasons for their satisfaction while partly pleased users are enjoying a reduction in expenditures to some extent. This variable also indicates that biogas plants are promised a solution to improve the financial status of the household.

\section{Environmental Adopters}

It is evident from the Table 5, that after the installation of biogas plant the major benefits associated with fitness and cleanliness are a significant drop in fire accidents, 
freedom from sickness related to smoke and deficiency of black dirt in-house/kitchen. 32\% respondents highlight the significant drop in fire accidents, $14 \%$ reported freedom from sickness related to smoke and deficiency of black dirt in house/kitchen respectively and $8 \%$ agreed to a reduction of everyday expenditures related to fitness in response to the question "main benefits of biogas plants associated with fitness and cleanliness". $43 \%$ did not respond to the question as denoted None in the figure.

Table 5. Major benefits associated with fitness and cleanliness.

\begin{tabular}{|c|c|c|c|c|}
\hline Variable & Description & Frequency & $\begin{array}{c}\text { Percent of } \\
\text { response (\%) }\end{array}$ & $\begin{array}{c}\text { Percent of cases } \\
(\%)\end{array}$ \\
\hline \multirow{5}{*}{$\begin{array}{l}\text { Main benefits of biogas } \\
\text { plants associated with } \\
\text { fitness and cleanliness }\end{array}$} & $\begin{array}{l}\text { Freedom from sickness related to } \\
\text { smoke }\end{array}$ & 7 & 12.5 & 13.7 \\
\hline & Significant drop in fire accidents & 16 & 28.6 & 31.4 \\
\hline & $\begin{array}{l}\begin{array}{l}\text { Deficiency of black } \\
\text { house/kitchen }\end{array} \\
\end{array}$ & 7 & 12.5 & 13.7 \\
\hline & $\begin{array}{l}\text { Reduction of everyday expenditures } \\
\text { related to fitness }\end{array}$ & 4 & 7.1 & 7.8 \\
\hline & None & 22 & 39.3 & 43.1 \\
\hline
\end{tabular}

\section{Challenging Factors}

Table 6, lists various discouraging factor for partial adaptation of biogas plants. The highest response percentage of $15.7 \%$ attributed to unavailability of technicians. Whereas low pressure of biogas, frequent operational problems were $12 \%$ respectively. Operational problems mainly include gas pressure leakages, crack development in walls and roof of the biogas plants, corrosion of the steel parts (Zemo et al., 2019), (Scheutz and Fredenslund, 2019). The lowest response percentage was $3.9 \%$ for the reason that due to low pressure the food is not well cooked. The low pressure is mainly due to poor mixing of feed inside the reactor. (Nsair et al., 2019) studied the stirring mechanism in biogas plants to improve the gas pressure requirement for the end-user.

The second section of the table addressed the complete dissatisfaction of the plant owners. $20 \%$ of the owners complained about frequent technical problems that hinder the smooth operation of the biogas plant. Similarly, no technical support, gas leakages were $12 \%$ and extra workload to handle the biogas was $14 \%$ respectively. These factors contribute to failure or discouragement of the biogas plant users. The lack of technical support is attributed to a policy framework for the project. (Pandyaswargo et al., 2019) mentioned that the sustainability of a biogas plant project is negatively affected in the absence of supporting system running in the background which includes technical assistance.

In case of general problems, $39.2 \%$ linked it with the poor operation (more or less feed of dung and water) and the lower response percentages $1.5 \%, 2.2 \%$ and $2.9 \%$ and case percentages $3.9 \%, 5.9$ and $7.8 \%$ are the attachment of toilet is un-sacred, bio-slurry management issues and poor services during installation respectively. These factors attribute to awareness of the end-user to operate the plant. The major reasons due to which respondents are partly pleased with their biogas plants are unavailability of technicians, insufficient gas for food preparation/lighting, difficulty in operation of biogas plant and frequent encounter with technical problems. These are the major hurdles in the acceptance of biogas plants in rural areas of Faisalabad. The visuals of abandoned biogas plants are illustrated in figure 3 . 
Table 6. Challenging factors.

\begin{tabular}{|c|c|c|c|c|}
\hline Variable & Description & Frequency & $\begin{array}{c}\text { Percent of } \\
\text { response }(\%)\end{array}$ & $\begin{array}{l}\text { Percent of } \\
\text { cases }(\%)\end{array}$ \\
\hline \multirow{7}{*}{$\begin{array}{l}\text { Reason(s) for being } \\
\text { partly please with } \\
\text { biogas plant }\end{array}$} & $\begin{array}{l}\text { Insufficient gas for food preparation } \\
\text { /Lighting }\end{array}$ & 6 & 8.0 & 11.8 \\
\hline & Difficulty in operation of biogas plant & 6 & 8.0 & 11.8 \\
\hline & $\begin{array}{llll}\text { Frequently come } & \text { across } & \text { technical } \\
\text { problems }\end{array}$ & 6 & 8.0 & 11.8 \\
\hline & Extra workload & 4 & 5.3 & 7.8 \\
\hline & Prepared food is not delicious & 2 & 2.7 & 3.9 \\
\hline & Unavailability of technicians & 8 & 10.7 & 15.7 \\
\hline & Others & 4 & 5.3 & 7.8 \\
\hline \multirow{10}{*}{$\begin{array}{l}\text { Reason(s) } \\
\text { abandoned } \\
\text { plant }\end{array}$} & Seldom cease to work properly & 6 & 6.3 & 11.8 \\
\hline & $\begin{array}{l}\text { Insufficient gas for food preparation } \\
\text { /Lighting }\end{array}$ & 7 & 7.4 & 13.7 \\
\hline & Difficulty in operation of biogas plant & 4 & 4.2 & 7.8 \\
\hline & $\begin{array}{llll}\begin{array}{l}\text { Frequently } \\
\text { problems }\end{array} & & & \text { acome } \\
\end{array}$ & 10 & 10.5 & 19.6 \\
\hline & Extra workload & 7 & 7.4 & 13.7 \\
\hline & Food prepared in biogas is not tasty & 6 & 6.3 & 11.8 \\
\hline & Unavailability of technicians & 8 & 8.4 & 15.7 \\
\hline & Escape of gas through joints /Connections & 6 & 6.3 & 11.8 \\
\hline & Malfunctioning of stoves & 4 & 4.2 & 7.8 \\
\hline & Others & 8 & 8.4 & 15.7 \\
\hline \multirow{15}{*}{$\begin{array}{l}\text { General problem }(\mathrm{s}) \\
\text { or reasons of failure } \\
\text { in proper working of } \\
\text { biogas plant }\end{array}$} & Poor material used for construction & 9 & 6.6 & 17.6 \\
\hline & Poor services during installation & 4 & 2.9 & 7.8 \\
\hline & $\begin{array}{l}\text { Poor / outdated } \\
\text { Design }\end{array}$ & 9 & 6.6 & 17.6 \\
\hline & $\begin{array}{l}\text { Poor operation (more or less feed of dung } \\
\text { and water) }\end{array}$ & 20 & 14.6 & 39.2 \\
\hline & $\begin{array}{l}\text { Poor maintenance or unavailability of } \\
\text { technicians }\end{array}$ & 13 & 9.5 & 25.5 \\
\hline & Unavailability of spare parts & 10 & 7.3 & 19.6 \\
\hline & Manmade / Natural disaster & 9 & 6.6 & 17.6 \\
\hline & $\begin{array}{l}\text { Attachment of } \\
\text { toilet is un-sacred }\end{array}$ & 2 & 1.5 & 3.9 \\
\hline & Obstruction in pipeline due to bio-slurry & 10 & 7.3 & 19.6 \\
\hline & Pipeline blockage due to condensed water & 9 & 6.6 & 17.6 \\
\hline & $\begin{array}{l}\text { Availability of natural gas by local gas } \\
\text { distribution authority }\end{array}$ & 6 & 4.4 & 11.8 \\
\hline & $\begin{array}{l}\text { Unavailability of skilled person who } \\
\text { operate and maintain biogas plant }\end{array}$ & 11 & 8.0 & 21.6 \\
\hline & Increased workload & 7 & 5.1 & 13.7 \\
\hline & Bio-slurry management issues & 3 & 2.2 & 5.9 \\
\hline & Others & 15 & 10.9 & 29.4 \\
\hline
\end{tabular}




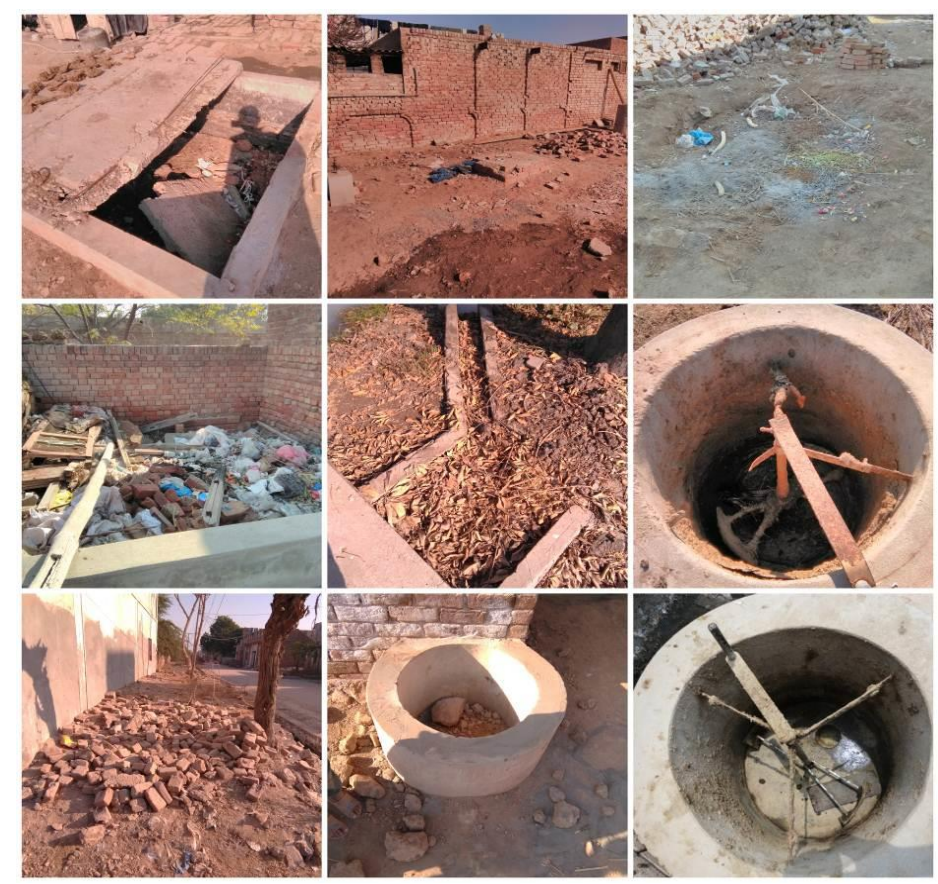

Figure 3. Visuals of abandoned biogas plants in rural areas of Faisalabad.

Table 7, shows that the frequency of trade of biogas is very low even among fully pleased users. The reason could be the low production of biogas, so people hardly meet their demands. Another reason is the lack of technical knowledge in the establishment of shared connections safely and successfully.

Table 7. Trade of Biogas.

\begin{tabular}{lcccc}
\hline Variable & Description & Frequency & Percentage & Mean \pm St. Dev. \\
\hline \multirow{3}{*}{ Trade biogas to another household } & None/no response & 22 & 43.1 & \\
& Yes & 1 & 2.0 & $1.12 \pm 0.993$ \\
& No & 28 & 54.9 & \\
\hline
\end{tabular}

\section{CONCLUSION AND RECOMMENDATIONS}

Biogas as a powerful source of renewable energy is well accepted globally. But in Low-middle income countries especially in Pakistan, it has not been accepted at an encouraging rate. Although efforts have been made by the government of Pakistan and some NGOs / INGOs by providing subsidized biogas plants to local farmers but still the acceptance of said technology is quite low among rural communities. According to energy choice theory, the residents of the study area show interest to use indigenous biogas from their own farms. However successful operation \& maintenance of biogas plants was a major issue. Furthermore, the untrained or partially trained person in the area, unavailability of technicians and skilled operator of biogas plant and no nearby technical service centers of biogas plants is second bottleneck reported. Lastly, the respondents did not get after-sales services by the installation/construction body. Therefore, it is recommended to devise a clear policy for technical support, capacity building sessions, short courses for operation and maintenance and launching a media complain for promotion of biogas technology. Pakistan has ample potential for biogas technology which can easily overcome domestic energy shortage issues. Thus, the government of Pakistan, relevant NGO/INGO should launch some training initiatives for smooth operation and maintenance of biogas plants to launch any realistic sustainable development project in the rural communities. Therefore, the government of Pakistan, relevant NGO/INGO should develop nearby technical centres and to recruit skilled technicians to provide installation, maintenance and aftersales services to the consumers. 


\section{REFERENCES}

Abbas, T., G. Ali, S. A. Adil, M. K. Bashir and M. A. Kamran. 2017. Economic analysis of biogas adoption technology by rural farmers: The case of Faisalabad district in Pakistan. Renewable Energy, 107: 431-39.

Aberilla, J. M., A. Gallego-Schmid, L. Stamford and A. Azapagic. 2020. Environmental sustainability of cooking fuels in remote communities: Life cycle and local impacts. Science of The Total Environment, 713: 136445.

Afridi, Jing and Younas. 2019. Biogas Production and Fundamental Mass Transfer Mechanism in Anaerobic Granular Sludge. Sustainability, 11: 4443.

Afridi, Z. U. R. and N. W. Qammar. 2020. Technical Challenges and Optimization of Biogas Plants. ChemBioEng Reviews, 7: 119-29.

Akinbami, J.-F., M. Ilori, T. Oyebisi, I. Akinwumi and 0. Adeoti. 2001. Biogas energy use in Nigeria: current status, future prospects and policy implications. Renewable and Sustainable Energy Reviews, 5: 97-112.

Akram, W., H. D. Lohano and J. Inayatullah. 2017. Adoption of Biogas: A Story from Rural Pakistan. 2017 Annual Meeting, July 30-August 1, Chicago, Illinois 258206, Agricultural and Applied Economics Association.

Alvi, J., I. Ashraf, K. M. Ch, M. Iftikhar and S. Ashraf. 2015. Impact of livestock in uplifting rural livelihood. Pakistan Journal of Agricultural Research, 28.

Amer, M. and T. U. Daim. 2011. Selection of renewable energy technologies for a developing county: a case of Pakistan. Energy for Sustainable Development, 15: 420-35.

Amir, S. M., Y. Liu, A. A. Shah, U. Khayyam and Z. Mahmood. 2020. Empirical study on influencing factors of biogas technology adoption in Khyber Pakhtunkhwa, Pakistan. Energy \& Environment, 31: 308-29.

Ashraf, S., M. Luqman, Z. Y. Hassan and A. Yaqoob. 2019. Determinants of Biogas Technology Adoption in Pakistan. Pakistan Journal of Scientific \& Industrial Research Series A: Physical Sciences, 62: 113-23.

Baland, J. M., P. Bardhan, S. Das, D. Mookherjee and R. Sarkar. 2010. The Environmental Impact of Poverty: Evidence from Firewood Collection in
Rural Nepal. Economic Development and Cultural Change, 59: 23-61.

Bates, M. N., K. Pope, T. R. Sijali, A. K. Pokhrel, A. Pillarisetti, N. L. Lam and S. C. Verma. 2019. Household fuel use and pulmonary tuberculosis in western Nepal: A case-control study. Environmental Research, 168: 193-205.

Breitenmoser, L., T. Gross, R. Huesch, J. Rau, H. Dhar, S. Kumar, C. Hugi and T. Wintgens. 2019. Anaerobic digestion of biowastes in India: Opportunities, challenges and research needs. Journal of Environmental Management, 236: 396-412.

Chaudhry, M. A., R. Raza and S. A. Hayat. 2009. Renewable energy technologies in Pakistan: prospects and challenges. Renewable and Sustainable Energy Reviews, 13: 1657-62.

Clemens, H., R. Bailis, A. Nyambane and V. Ndung'u. 2018. Africa Biogas Partnership Program: A review of clean cooking implementation through market development in East Africa. Energy for Sustainable Development, 46: 23-31.

GoP. 2018. Energy Yearbook edited by HDIP. Pakistan.

Economic survey of Pakistan. 2019. In Finance Devision (Ed.),Government of Pakistan. Islamabad, Pakistan.

Heltberg, R. 2005. Factors determining household fuel choice in Guatemala. Environment and Development Economics, 10: 337-61.

Hettiarachchi, H., J. Meegoda and S. Ryu. 2018. Organic Waste Buyback as a Viable Method to Enhance Sustainable Municipal Solid Waste Management in Developing Countries. International Journal of Environmental Research and Public Health, 15: 2483.

Iqbal, S., S. Anwar, W. Akram and M. Irfan. 2013. Factors leading to adoption of biogas technology: a case study of District Faisalabad, Punjab, Pakistan. International Journal of Academic Research in Business and Social Sciences, 3: 571.

Jamil, F. and E. Ahmad. 2010. The relationship between electricity consumption, electricity prices and GDP in Pakistan. Energy policy, 38: 6016-25.

Masera, O. R., B. D. Saatkamp and D. M. Kammen. 2000. From Linear Fuel Switching to Multiple Cooking Strategies: A Critique and Alternative to the Energy Ladder Model. World Development, 28: 2083-103.

Matter, A., M. Ahsan, M. Marbach and C. Zurbrügg. 2015. 
Impacts of policy and market incentives for solid waste recycling in Dhaka, Bangladesh. Waste Management, 39: 321-28.

Morgan, H. M., W. Xie, J. Liang, H. Mao, H. Lei, R. Ruan and Q. Bu. 2018. A techno-economic evaluation of anaerobic biogas producing systems in developing countries. Bioresource Technology, 250: 910-21.

Mushtaq, K., A. A. Zaidi and S. J. Askari. 2016. Design and performance analysis of floating dome type portable biogas plant for domestic use in Pakistan. Sustainable Energy Technologies and Assessments, 14: 21-25.

Nevzorova, T. and V. Kutcherov. 2019. Barriers to the wider implementation of biogas as a source of energy: A state-of-the-art review. Energy Strategy Reviews, 26: 100414.

Nsair, A., S. Ö. Cinar, H. A. Qdais and K. Kuchta. 2019. Optimizing the performance of a large scale biogas plant by controlling stirring process: A case study. Energy Conversion and Management, 198: 111931.

Oyeleke, O. J. and T. Akinlo. 2020. Energy generation and economic growth: empirical evidence from Nigeria. Environment, Development and Sustainability, 22: 7177-91.

Pandyaswargo, A. H., P. Jagath Dickella Gamaralalage, C. Liu, M. Knaus, H. Onoda, F. Mahichi and Y. Guo. 2019. Challenges and an implementation framework for sustainable municipal organic waste management using biogas technology in emerging Asian Countries. Sustainability, 11: 6331.

Pham, C. H., S. Saggar, C. C. Vu, K. R. Tate, T. T. Tran, T. T. Luu, H. T. Ha, H. L. Nguyen and S. G. Sommer. 2017. Biogas production from steer manures in Vietnam: Effects of feed supplements and tannin contents. Waste Management, 69: 492-97.

Pilloni, M., T. A. Hamed and S. Joyce. 2020. Assessing the success and failure of biogas units in Israel: Social niches, practices, and transitions among Bedouin villages. Energy Research \& Social Science, 61: 101328.

Prochnow, A., M. Heiermann, M. Plöchl, B. Linke, C. Idler,
T. Amon and P. Hobbs. 2009. Bioenergy from permanent grassland-A review: 1. Biogas. Bioresource Technology, 100: 4931-44.

Puzzolo, E., D. Pope, D. Stanistreet, E. A. Rehfuess and N. G. Bruce. 2016. Clean fuels for resource-poor settings: a systematic review of barriers and enablers to adoption and sustained use. Environmental Research, 146: 218-34.

Rehman, A., L. Jingdong, A. A. Chandio and I. Hussain. 2017. Livestock production and population census in Pakistan: Determining their relationship with agricultural GDP using econometric analysis. Information Processing in Agriculture, 4: 168-77.

Rosenthal, J., A. Quinn, A. P. Grieshop, A. Pillarisetti and R. I. Glass. 2018. Clean cooking and the SDGs: Integrated analytical approaches to guide energy interventions for health and environment goals. Energy for Sustainable Development, 42: 152-59.

Scheutz, C. and A. M. Fredenslund. 2019. Total methane emission rates and losses from 23 biogas plants. Waste Management, 97: 38-46.

Shah, A. A. and A. R. Sahito. 2017. Appraisal of Biogas Potential of Biogas from Animal Dung in Saeedabad, Pakistan. Mehran University Research Journal of Engineering and Technology, 36: 70718.

Shrestha, S. and S. Dhakal. 2019. An assessment of potential synergies and trade-offs between climate mitigation and adaptation policies of Nepal. Journal of Environmental Management, 235: 535-45.

Wang, Z. and M. M. Calderon. 2012. Environmental and economic analysis of application of water hyacinth for eutrophic water treatment coupled with biogas production. Journal of Environmental Management, 110: 246-53.

Younos, T., R. Hill and H. Poole. 2012. Water dependency of energy production and power generation systems. Water Resources Impact, 14: 9-12.

Zemo, K. H., T. E. Panduro and M. Termansen. 2019. Impact of biogas plants on rural residential property values and implications for local acceptance. Energy policy, 129: 1121-31. 
Publisher's note: EScience Press remains neutral with regard to jurisdictional claims in published maps and institutional affiliations.

(c)

Open Access This article is licensed under a Creative Commons Attribution 4.0 International License, which permits use, sharing, adaptation, distribution and reproduction in any medium or format, as long as you give appropriate credit to the original author(s) and the source, provide a link to the Creative Commons license and indicate if changes were made. The images or other third-party material in this article are included in the article's Creative Commons license, unless indicated otherwise in a credit line to the material. If material is not included in the article's Creative Commons license and your intended use is not permitted by statutory regulation or exceeds the permitted use, you will need to obtain permission directly from the copyright holder. To view a copy of this license, visit http://creativecommons.org/licenses/by/4.0/. 